\title{
Exemptions from punishment in China and Thailand from the perspective of the theory of Leon Petrazycki*
}

\author{
Alexandre N. Chitov
}

For citation: Chitov, Alexandre N. 2018. Exemptions from punishment in China and Thailand from the perspective of the theory of Leon Petrazyck. Pravovedenie 62 (3): 570-581.

https://doi.org/10.21638/11701/spbu25.2018.309

This paper compares legislative provisions of Chinese and Thai laws pertaining to exemptions from punishment. These exemptions must be distinguished from the exemptions from criminal liability. In the latter case, Chinese and Thai courts cannot inflict punishment on a person who is justified or excused in committing an act otherwise defined as a crime. In contrast, an exemption from punishment is granted by courts as an exercise of discretionary powers. Chinese and Thai laws bear similar characteristics in defining the exemptions from criminal liability, but differ significantly in the scope of discretionary powers of courts to exempt from punishments. Chinese law allows judges to have more discretion in not imposing penalties on an offender than Thai law does. The reason for the difference lies in a greater openness of Chinese law to moral considerations to be played in sentencing practices. Thai law is much more influenced by the philosophy of legal positivism. These similarities and differences are discussed in the light of the theory of Leon Petrazycki. It is argued that Petyrazycki's concept of intuitive law as attributive imperatives is important in explaining and justifying the powers of the court not to inflict punishment if it meets the goals of criminal justice. From the viewpoint of the theory of Petrazycki, Chinese law can accommodate better the intuitive law of the public to the exigencies of various social situations. However, Petrazycki's theory alone cannot override many reasons against giving judges extensive powers to apply their intuitive laws to exempt offenders from punishment. There is a plurality of psychological imperatives which may conflict with each other. To resolve those conflicts, it is necessary to draw on the idea of natural law. Even though Petrazycki did not explicitly argue for the existence of the natural law, its existence can be drawn from common psychological imperatives as well as from a striking similarity between various systems of criminal law in such diverse countries as China and Thailand. Many of the legal provisions of their laws display certain common legal paradigms that cannot be only accounted for by the adoption of the Western legal concepts.

Keywords: criminal liability, punishment, Thailand, China, psychological theory of law, Petrazycki.

\section{Introduction}

The exemption from punishment is defined here as an exercise of discretionary powers by courts not to inflict penalties on an offender. In this sense, it is different from the exemptions from criminal liability. The amount of literature on the relationship between criminal liability and punishment is enormous. It is commonly asserted that "criminal liability is the strongest formal censure that society can inflict, and it may also result in a

* This paper is based on the research program funded by the Thailand Research Fund (TRF)

Alexandre Chitov - Assist. Professor, Chiang Mai University, 239 Huay Kaew Road, Chiang Mai 20500, Thailand; shytov@yahoo.com

(C Санкт-Петербургский государственный университет, 2019 
sentence which amounts to a severe deprivation of the ordinary liberties of the offender"1. Therefore, one has to acknowledge that being subject to criminal liability does not always mean to be subject to punishment. As another writer has rightly put it: "'To be liable to punishment' means 'may, according to the rules, be punished.' It does not necessarily mean 'deserved to be punished'. Furthermore, liability need not entail actual punishment any more than being culpable entails actually being blamed. Of course, some pronouncements of desert ('You are to blame for this.') are acts of blaming. The culpability of the agent, however, is a prerequisite of just blaming. In the same way, while 'liable to punishment' is often taken to mean 'will be punished', liability is distinct from actual punishment. It is in this sense that legal liability is understood as candidacy for punishment"2.

The distinction between being liable to punishment and being deserved to be punished is particularly appropriate to describe the conflict between the official law and the standards of law maintained by one's conscience. There can be many situations when one can see that a person liable to punishment does not deserve it, and a person who deserves it may not be liable. This conflict has been well described by a Russian scholar of Polish descent, Leon Petrazycki ${ }^{3}$, more than a hundred years ago. His theory of intuitive law deserves a recognition and attention by the modern philosophy of criminal justice. Its significance becomes more apparent after taking cognizance of Petrazycki's understanding of legal responsibility. His ideas have been explored, to some extent, in several works ${ }^{4}$. However, almost all the books of Petrazycki (his heritage amounts to 35 volumes) are still inaccessible to an English speaking reader. There is only one shortened translation of his two volume work Theory of Law and State, published by the Harvard University Press in 1955.

Petrazycki's approach to legal responsibility to some extent reflects the same concern found among the leading British legal theorists, that the treatment of criminal liability often misses the relational dimensions of criminal responsibility (Duff 2007, 15) ${ }^{5}$. Unlike Duff, Petrazycki does not attempt to draw fine distinctions between the meanings of liability and responsibility. Instead, he analyses the moral nature of impulsions that bring about the norms of criminal justice as well as of other branches of law. The implications of his theory for criminal law are particularly of interest in the Far Eastern context, which does not easily accommodates the Western philosophical categories of criminal justice ${ }^{6}$.

The application of Petrazycki's theory is limited here to a critical examination of Chinese and Thai legislative provisions on exemptions from punishment. It implies that allowing a broader scope of judicial discretion in exempting offenders from punishment does not mean an admission of arbitrariness and a disregard for the principle of legality. In order to meet the interests of justice in particular cases, the law must give space for judicial discretion. According to this theory, judges are compelled to follow the intuitive law. The problem, however, arises when intuitive laws are conflicting with each other. As it will

1 Ashworth A., Horder J. Principles of criminal law. Oxford: University Press, 2013. P. 1.

2 Sistare C. T. Responsibility and Criminal Liability. Vol. 7. Heidelberg: Springer Science \& Business Media, 1989. P. 17.

3 Petrazycki L. Theory of Law and State. St. Petersburg: Merkushev, 1910.

4 Gorecki J. Sociology and jurisprudence of Leon Petrażycki. Urbana: University of Illinois Press, 1975; Rudzinski A.W. Petrazycki's Significance for Contemporary Legal and Moral Theory // American Journal of Jurisprudence. 1976. No.21. P. 107-130; Sadurska R. Jurisprudence of Leon Petrazycki // American Journal of Jurisprudence. 1987. No. 32. P. 63-98.

5 Duff R. A. Answering for crime: Responsibility and liability in the criminal law. Oxford: Hart Publishing, 2007. P. 15.

6 For example, Duff's distinction between criminal responsibility and criminal liability does not make sense in Chinese or Thai languages as they mean the same thing. The Chinese term 刑事责任 as well as the Thai term ความรับผิดในทางอาญา mean both criminal liability and criminal responsibility. 
be demonstrated below, Petrazycki, despite his concern for a rational legal policy, does not offer the solution to reconcile conflicting intuitive laws in relation to exemptions from punishment. It is argued that this basis can be found in the concept of intuitive natural law.

\section{Exceptions from criminal liability in Chinese and Thai laws}

In order to understand better the differences between Thai and Chinese laws on the exemptions from punishment, one has to look first at the exemptions from criminal liability as reflected in the respective laws. There is a striking similarity in the exemptions from criminal liability found in Thai and Chinese legislation despite the differences in their expressions. For example, Article 16 of Criminal Law of the People's Republic of China $(1979,1997,2011)$ states that an act is not a crime if it objectively results in harmful consequences due to irresistible or unforeseeable causes rather than intent or negligence. Thai criminal law (Thai Penal Code ประมวล กฎหมายอาญา ฉบับ พิมพ์ พ. ศ. (2558)) does not contain explicitly such a provision. It only states in Section 59 that "a person shall be criminally liable only when such a person commits an act intentionally, except in cases when the law provides that such a person commits an act by negligence, or except in cases when the law clearly provides that such a person must be liable even though committing an act unintentionally." The last part of the Section can be interpreted as allowing criminal liability in cases when there is neither intent nor negligence, if the legislator explicitly chooses so. In other words, Chinese criminal law is more restrictive by forbidding imposition of criminal liability in the cases of harm caused objectively beyond intent or negligence of a person.

From reading Article 16 of Chinese Criminal Law, one may suppose that criminal liability is limited only to the situations of intentional or negligent harm which already occurred. However, the harm principle, is not the only basis for criminalization policies adopted by the Chinese legislators. Article 13 maintains a different principle: crime is an act that endangers (危害) society. In a number of provisions dealing with specific offences, Chinese law criminalizes acts that are done in violation of state regulations even if there are no harmful consequences. ${ }^{7}$

Article 17 of Chinese Criminal Law exempts all minors from criminal liability who did not reach the age of 16 at the time of offence (or 14 years in cases of intentional homicide or injury, rape, robbery, drug-trafficking, arson, explosion or poisoning). However, the court can order the head of the young offender's family or a guardian to discipline (加以 管教) the offending youth. Thai law (Section 73) exempts from criminal liability children below 7 years old. The same applies to the children between 7 and 14, but the court has the power to admonish the child, or to give an appropriate order to the parents or guardians, or to hand the child over to a person or organization which is suitable to take care of him.

In relation to mentally ill persons (精神病人), the Chinese law stipulates that they are not liable at a time when they are unable to recognize or control their own conduct. If a mental patient does not lose completely the ability of recognizing or controlling his own conduct, he shall still be liable, although he may deserve a lighter punishment (Article 18). Thai law exempts not only mentally ill people but also any offender who at the time of committing an offence "was not able to appreciate the nature, or illegality of his act (ไม่สามารถ รู้ผิดชอบ) or not being able to control himself on account of defective mind (มีจิตบกพร่อง), mental disease (โรคจิต) or mental infirmity (จิตฬันเพือน)" (Section 65). Such a wording can

7 See for example Article 185a which penalizes the use of public funds (however beneficial or not harmful it might be) in violation of state regulations. 
exempt from criminal liability any person who could not appreciate the nature of their actions or were not able to control themselves by any other reason than mental illness. For example, certain defects of mind can be caused by aging (Zarit \& Zarit 2012, 5) ${ }^{8}$, or by other illnesses not clinically classified as mental illnesses.

The narrow construction of the meaning of mental disorders may had influenced the Chinese legislators when they gave the power to the courts to reduce punishment of old people above the age of 75 (Article 17a). Considering the broad provisions of Section 65, Thai law does not need to offer a different treatment for old people, although there are some provisions which require to consider the age of the sentenced person in relation to social services (Section 30/1), or suspension of imprisonment sentence (Article 56).

Further, Chinese law explicitly excludes intoxicated persons from the exceptions to criminal liability (Article 18). Thai law again offers a more flexible approach exempting from criminal liability those who are intoxicated without their knowledge or against their will, if they are unable to understand the nature of their acts or unable to control themselves (Section 66).

Article 20 of Chinese Criminal Law excludes any person from criminal liability who acted in justifiable defence. It is defined as any act that "a person commits to stop an unlawful infringement in order to prevent the interests of the state and the public, or his own or other person's rights of the person, property, or other rights from being infringed upon by the on-going infringement, thus harming the perpetrator." This, however, must not exceed the limits of necessity. Similarly, Thai Penal Code requires (Section 68) that the defence must be reasonable (กระทำพอสมควรแก่เหตุ) in order to avoid completely criminal liability.

The exclusion of criminal liability on the ground of necessity is similarly regulated by the criminal laws of China and Thailand. Article 21 of Chinese law states that "if a person is compelled to commit an act in an emergency to avert an immediate danger to the interests of the State or the public, or his own or another person's rights of the person, property or other rights, thus causing damage, he shall not bear criminal liability." However, Thai law defines necessity somewhat wider as including, apart from the situations of emergency to avert a danger to the public or private interests, also the situations when a person "is under compulsion or under the influence of a force that he cannot avoid or resist" (Section 67).

One significant difference between Chinese and Thai legislation is that Thai law explicitly excludes criminal liability in cases of a mistake of fact (Section 62). This section has been used by Thai courts to exclude from criminal liability a person who shot a person who thought to be attacking the accused (Thai Supreme Court 1873/2522, p. 1554), a person who forced a woman to sexual intercourse supposing her to remain his lawful wife (Thai Supreme Court 430/2532, p. 395); a person who destroyed a fence of a neighbor mistakenly supposing the fence to be on his territory (Thai Supreme Court 89/2519, p. 53), etc. Nevertheless, the mistake of fact is also known to Chinese criminal law theory and is used in establishing the lack of intent ${ }^{9}$, even though it is not expressed in the text of Chinese Criminal Law.

There are some other differences. In a number of offences, particularly related to property, the spouse of the victim is exempted from criminal liability according to Thai Penal Code (Section 71). No such an exemption exists in Chinese law. Another difference is that Thai law (Section 70) exempts from criminal liability anyone who acts in accordance

8 Zarit S. H., Zarit J. M. Mental disorders in older adults: Fundamentals of assessment and treatment. New York: Guilford Press, 2011. P. 5.

9 Badar M. E. The concept of Mens Rea in international criminal law: The case for a Unified Approach. Oxford: Hart Publishing, 2013. P. 188. 
with an illegal order of an official, if he has a duty to comply with the order unless that person knows that the order is unlawful. Chinese law does not have a similar provision.

Despite these differences in defining exemptions from criminal liability, Chinese and Thai laws are remarkably similar. How can we explain this similarity between so diverse countries? One reason can be the influence of the Western law through the processes of globalization. However, this explanation may be superficial. The analysis of the exemptions from punishment based on the discretionary powers of courts illustrates the fact that Chinese and Thai criminal law provisions can also be very different.

\section{Exemptions from punishment and the discretionary powers of courts}

The exemptions from punishment can be not only mandatory but also be based on the discretion of courts. The line between the exemptions from criminal liability and exemptions from punishment may not always be clear, particularly in the circumstances of specific cases. There are many provisions in Chinese Criminal law which give the power to the courts not to inflict punishment on the defendant who committed an offence. A person, who exceeded limits of necessity while defending oneself or others, according to Chinese law, "shall be given a mitigated punishment or be exempted from punishment" (Article 20, 21). Thai law, in contrast, does not permit a complete exemption from liability unless a criminal act occurs "out of excitement, fright or fear". In this case, the exemption is mandatory (Section 69). In other cases of exceeding justifiable limits, Thai courts are allowed to reduce but not to exempt from punishment completely.

Further, Chinese Criminal Law contains a very flexible provision that "anyone who is coerced to participate in a crime shall be given a mitigated punishment or be exempted from punishment in the light of the circumstances of the crime he commits" (Article 28). In other words, Chinese courts have discretion to exempt or not exempt from punishment those who are coerced in taking part in a criminal activity. A similar provision apples to accomplices who play a secondary or auxiliary role in a joint crime (Article 27). In contrast, Thai law requires that such an accomplice is punished by two-thirds of the punishment imposed for a particular crime (Section 86).

There are other occasions when Chinese law gives discretion to the courts to exempt a person committing an offence from punishment. For example, deaf-mute or blind people can be completely exempted from punishment or the punishment can be reduced (Article 19). Article 22 allows courts, without specifying the reasons, to exempt from punishment those who prepare for a crime but do not commit. This is different from the cases when an offender voluntarily discontinues the crime and effectively prevents the consequences of the crime from occurring, he must be exempted from punishment if no damage is caused (Article 24). In the latter cases, exemption from punishment is mandatory. Thai law contains a similar mandatory exemption. The person who attempts crime but then "voluntarily desists from carrying it through, or changes his mind and prevents the act from achieving its end" must be exempted from punishment (Section 82).

Further, Article 37 of Chinese law states that "if the circumstances of a person's crime are minor and do not require criminal punishment, he may be exempted from it; however, he may, depending on the different circumstances of the case, be reprimanded or ordered to make a statement of repentance, offer an apology or pay compensation for the losses, or be subjected to administrative penalty or administrative sanctions by the competent department." Thai law generally does not give discretion to the courts to exempt from punishment. An exception is in inflicting punishment on an offender over 14 years old but not over 17 years (Section 75) and for attempting crime by acting "out of besotted belief" (โดยความเชือ อย่างงมงาย) (Section 81). Besotted belief is understood as largely the one which is caused 
by a superstition or a belief in magic (Thai Supreme Court, 4495/2546). Chinese contemporary law ignores the use of magic to harm other persons all together, although the ancient law of this country considered the use of sorcery among the ten abominations which were punished the most severely (Tang Code, Chapter 1 , Article $6(5))^{10}$.

Thus, despite many similarities in relation to the exemptions from criminal liability, Chinese and Thai criminal laws differ fundamentally as Chinese law gives judges greater discretionary powers not to inflict punishment on offenders. In this respect, the question arises whether or not Thai law does better by adhering to the principle of legality more strictly than Chinese criminal law. The underlying philosophy of Thai criminal law is following. If law makes an offence liable to punishment, it is obvious that the task of the courts is to enforce law. Criminal law offences must be constructed strictly and applied equally. If there are exceptions from punishment, these exceptions must be specific and clearly articulated in law. Consequently, granting broad discretionary powers to the courts in exempting offenders from punishment goes against the principle of legality ${ }^{11}$.

However, the Chinese approach may address better the interests of social policy and even traditional morality not to punish offenders in the cases when the consequences of crime are not serious or the offender does not represent a danger to the society ${ }^{12}$. This can be particularly seen in Article 37 that allows the courts, instead of punishment, to reprimand, to order to make a statement of repentance or offer an apology, or to pay compensation for the losses, etc. It conforms better than Thai law to the idea of a criminal trial as a spectacle of public censure ${ }^{13}$ without the necessity to inflict a penalty on a convicted offender.

In Chinese law, as well as in the few discussed instances of Thai law, the nature of the powers of the courts not to inflict punishment is not always obvious. When a court decides not to impose punishment on a person, does it mean that the perpetrator of an act otherwise punishable does not deserve it, or he remains to be blamed but punishment is not inflicted on the considerations of mercy? ${ }^{14}$ Is this power the way through which judges can bring their moral perceptions of crime into play? If so, does it not contradict the principle of the rule of law? The theory of intuitive law developed by a Russian legal scholar of Polish descent, Leon Petrazycki ${ }^{15}$, contains answers to those questions.

10 See also: Benn C.D. China's Golden Age: Everyday Life in the Tang Dynasty. Oxford: University Press, 2004. P. 197. - English criminal law until the $18^{\text {th }}$ century was also less tolerant: "all persons invoking any evil spirit, or consulting, covenanting with, entertaining, employing, feeding, or rewarding any evil spirit; or taking up dead bodies from their graves to be used in any witchcraft, sorcery, charm, or enchantment; or killing or otherwise hurting any person by such infernal arts; should be guilty of felony and suffer death" (Blackstone W. Commentaries on the Laws of England. Oxford: Clarendon Press, 1769. P. IV, 6).

${ }^{11}$ Hallevy G. A modern treatise on the principle of legality in criminal law. Heidelberg: Springer science \& business media, 2010. P. 151.

12 For the influence of social policy and traditional ethics on Chinese law see: Chen J. Chinese Law: Context and Transformation. Leiden: Brill, 2015.

${ }^{13}$ Farmer L. Making the modern criminal law: Criminalization and civil order. Oxford: University Press, 2016. P. 19; Seredyńska I. Insider Dealing and Criminal Law: Dangerous Liaisons. Heidelberg: Springer Science \& Business Media, 2011. P. 145-146.

14 The latter view was advanced by John Tasioulas who considered mercy outside the retributive demands of criminal justice, see: Tasouilas J.: 1) Punishment and Repentance // Philosophy. 2006. No. 81. P. 279-322; 2) Repentance and the Liberal State // Ohio State Journal of Criminal Law. 2007. No. 4. P. 485-521; 3) Where is the Love. The Topography of Mercy // Crime, punishment, and responsibility: The jurisprudence of Antony Duff. Eds Cruft R., Kramer M. H., Reiff M. R. Oxford: University Press, 2011. P. 3753.

15 Petrazycki L. Theory of Law and State. 


\section{Psychological theory of Petrazycki and the discretionary power to exempt from punishment}

Petrazycki developed his theory of intuitive law on the basis of psychology of moral impulsion. According to him, in order to understand courts' judgements, one has to take into account not only the positive law that is set by the normative facts, that is a legislative directive, a legal custom, a judicial precedent ${ }^{16}$. It is also important to pay attention to the intuitive law which directs judges in making their decisions ${ }^{17}$. Intuitive law is based on a particular psychological experience of a legal obligation which is distinct from pure moral imperatives towards others. "Obligations conceived of as free with reference to others obligations as to which nothing appertains or is due from obligors - we will term moral obligations. Obligations which are felt as compulsory with reference to others - as made secure in their behalf — we shall term legal obligations" 18.

Thus, the legal obligations are expressed in, as he called it, attributive imperatives, and the moral obligations are expressed in non-attributive imperatives, because such imperatives are not accompanied by a right of the other person involved to the action caused by the imperative. Similarly to the positive law, intuitive law contains imperative-attributive imperatives. But unlike the positive law they are found in human consciousness independently from the normative facts such as a penal code. The intuitive law has a different source of the imperatives, which lies in the convictions and beliefs held by conscience. Both operate, however, together in what Petrazycki calls 'the official law'19. They have equally binding force on its subjects. Thus, the intuitive law is identified with the official law: "Insofar as they concern objects within the cognisance of official law, the axioms of intuitive law are acknowledged also by state courts and other organs of state authority. In general the corresponding intuitive law is a constituent part of official law and a fundamental and essential element thereof" 20 .

The positive law itself can be considered as a product and manifestation of the intuitive law of those who establish it, although not all of it is directly derived from the intuitive law. "Legislative enactments may be based on considerations of interests and the like, which contradict the intuitive law conscience of the legislators themselves - or of the masses - and nevertheless bring to life the corresponding positive law" ${ }^{21}$. There are also many parts of the positive law which are irrelevant and neutral with respect to the intuitive law: questions of formalities, technical arrangements, and so forth.

Petrazycki's theory contains an explanation and a justification of the discretionary powers of criminal courts to exempt a guilty offender from punishment. According to Petrazycki, the conflict between positive law and intuitive law is inevitable, and that it is in the court room where this conflict has to be settled. Not only may the intuitive law of one of the parties collide with the positive law, but so may the intuitive law of the judges whose role is to represent the intuitive law of the public ${ }^{22}$. The positive law and the intuitive law may coexist in relative harmony. This is a desired condition of the official law. In this context, one of the primary tasks of judges is to achieve this harmony. The intuitive law operates through interpretation of legal rules. "It exerts pressure upon the interpretation and ap-

16 Ibid. P. 477.

17 lbid. P. 486-487, 573.

18 Ibid. P. 49-50.

19 Petrazycki L. Law and Morality. Cambridge, Mass.: Harvard University Press, 1955. P. 292.

20 Ibid. P. 293.

21 Ibid. P. 235.

22 Ibid. P. 234. 
plication of positive law in the direction of securing decisions in accord with (or as little as possible divergent from) the directives of the intuitive law conscience" 23 .

According to Petrazycki, the legislation on criminal offences gives only a general pattern within which the intuitive law of the judges operates. The adaptation of general rules to concrete circumstances, the choice of the degree of punishment, or of the sum of an award, the evaluation of facts, - all these are governed by the intuitive law of the judges ${ }^{24}$. He writes: "In the official criminal law of civilised nations, the positive standardisation of punishments ordinarily indicates only the minimum and maximum limits of punishments, and definition of the specific punishments within these limits is left to the conscience of judges - that is to say, to their intuitive law. Even the decision as to whether or not the prisoner deserves punishment and should be recognised guilty (of an act which has been proved) depends on the conscience of judges and the jurors" 25 .

Thus, granting a greater degree of discretion to judges in exempting an offender from punishment does not mean that this issue is left to their arbitrary will to impose a penalty or not. In their capacity of a judge, they are bound by the intuitive law of the community. The advantage of a greater extent of the discretionary powers is that there will be less friction points between the intuitive law and the positive law which can render the application of criminal law more efficient. Therefore, the somewhat ambiguous formulations of Chinese criminal law on exemptions from punishment should not be perceived as a violation of the principle of rule of law. Rather, they express the intention of Chinese lawgiver to achieve some degree of social harmony by means of a more flexible approach to the infliction of, and the exemption from, punishment. It is noteworthy that social harmony is considered the ultimate objective of criminal law policy in China along with the rule of law ${ }^{26}$. In comparison, Thai criminal law does not offer a significant leeway to the courts to exempt an offender from punishment completely, although they retain powers to impose a lenient penalty if that is required by their intuitive law.

The implication of Petrazhicki' theory is that the existing discretionary powers to exempt an offender from punishment must not be perceived as a violation of the rule of law, or the principle of a uniform and equal applicability of general legal rules. The problem arises, however, when intuitive laws conflict with each other. In such situations, Petrazhicki was inclined to follow those attributive imperatives which are enlightened by the vision of a more desirable and rational law.

\section{Towards natural intuitive law}

Petrazycki did not believe in the existence of immutable, eternal, and universal norms identified with the natural law which the positive law must comply with ${ }^{27}$. He was influenced by the Historical School of Jurisprudence by considering the contents of both intuitive and positive laws as changeable and dynamic. At the same time, he was sympathetic to the movement of the revived natural law ${ }^{28}$. Petrazycki attempted "to initiate and substantiate the idea of the possibility and necessity of creating a special science - the policy of law on the basis of a psychological study of law and its motivational and cultural-educational impact; this science is dedicated, in contrast to the existing jurisprudence, engaged in a

23 Ibid.

24 Ibid. P. 293.

25 Ibid.

${ }^{26}$ Lijuan Xing. The Rhyme of History: A Transition of Legal Culture in China Crowned by the Criminal Procedure Law 2012 // Asia Pacific Law Review 23. 2015. No. 1. P. 31-65.

27 Petrazycki L. Theory of Law and State. Ch. IV.

28 Ibid. Ch. V. 
historical study and the practical-dogmatic elaboration of existing law, to the development of the foundations of desirable, rational law and legislation ${ }^{29}$.

Even though Petrazycki shared the prevalent skepticism towards the traditional theory of natural law, the search for the ideal of a desirable and rational law effectively places him within it. One can agree with Petrazycki that not all intuitive law is rational and desirable, and therefore, following the traditional terminology, not all intuitive law is natural. Intuitive law can be contradictory since it varies from an individual to an individual ${ }^{30}$. Therefore, in order to rationalize often irrational ethical impulsions that constitute individual intuitive law, one has to identify the standards of what is rational and desirable for the humankind. This is particularly important since the intuitive law is seen largely as the force which determines the appearance, change, and the destruction of positive law ${ }^{31}$. The discussion of the relationship between intuitive law and positive law is beyond the scope of this paper. The Petrazycki's ideas on their relevance to natural law has been considered to some extent somewhere else ${ }^{32}$. At this point, it is important to emphasize that the idea of intuitive natural law can be helpful in considering the exemptions from criminal liability and from punishment.

The similarities, such as found in Chinese and Thai criminal laws on exemptions from criminal liability, can be explained on the basis of psychological impulsions (in the meaning of Petrazycki's theory) which give rise to those exemptions. The justifiable defence and necessity are considered universally to be grounds for the exclusion of criminal liability. If it is so, then why not to define them as the requirements of intuitive natural law as well as positive law? Petrazycki himself would claim that these requirements are only common among, what he called, "civilized nations" 33 . It is true that not every intuitive law (particularly among the barbarians preferring the standards of strict liability) would justify or excuse "objectively wrongful actions" 34 in self-defence and necessity. However, already in the Biblical law of Moses (who allegedly lived somewhat sixteen hundred years before Jesus), we find the idea of justifiable killing in self-defence (Exodus, 22, 2-3). Jesus himself maintained that a person is not guilty of breaking sacred laws, whose violation was often punished by death, if acting out of necessity (Mathew, 12:14). In other words, there are some demands of intuitive law which cannot be reduced only to a particular civilized stage of legal development.

The idea of intuitive natural law seems logically flows from Petrazycki's search for the science of legal policy and for a better operation of criminal law in general. It is also important as an intellectual platform for a critical analysis of diverse contemporary practices of exempting from punishment. It helps to identify the reasons for possible exemptions.

29 Ibid. P. 378-379. - The Russian text runs as following: “Впрочем, в некоторой части новейшей литературы (последнего десятилетия XIX и начала XX столетия) появилось вновь признание естественного права, казавшегося окончательно и решительно устраненным из сферы научной мысли, и даже идет речь «о возрождении естественного права». Автор этого сочинения пытался путем ряда специальных исследований и основанных на них общих соображений возбудить и обосновать мысль о возможности и необходимости создания на почве психологического изучения права и его мотивационного и культурно-воспитательного действия особой науки - политики права, в частности - в области гражданского, цивильного права - цивильной политики, посвященной, в отличие от существующей юриспруденции, занимающейся историческим изучением и практически-догматической разработкой действующего права, разработке начал желательного, рационального права и законодательства".

30 Ibid. P. 381-382.

31 Ibid. P. 395-396.

32 Shytov A. N. Conscience and love in making judicial decisions. Heidelberg: Springer Science \& Business Media, 2001.

33 Petrazycki L. Theory of Law and State. P. 104. 2013).

34 The term is sometimes used in American criminal case law: In re Levasseur, 737 F.3d 814 ( $1^{\text {st }}$ Cir. 
Among the competing ethical imperatives on what and who should be excluded from punishment, the theory of Petrazycki would cogently require an appeal to a purer and nobler intuitive natural law.

\section{Conclusion}

Even though the positive law of diverse countries such as China and Thailand contain similar provisions on the exemption from criminal liability, there is a significant difference in relation to the discretionary exemptions from punishment. Chinese law allows judges to have more discretion in not imposing penalties on an offender than Thai law does. The reason for the difference lies in a greater openness of Chinese law to moral considerations to be played in sentencing practices. Thai law is much more influenced by the philosophy of legal positivism. Its credo is that "there is no straightforward moral or social test of whether conduct is criminal. The most reliable test is the formal one: is the conduct prohibited, on pain of conviction and sentence?"35. Petrazycki's approach challenges this commonly held belief. The test is found in the intuitive law that is experienced in attributive imperatives of our consciousness.

In this aspect, Chinese law can accommodate better the intuitive law of the public to the exigencies of various social situations. There can be many reasons against giving judges extensive powers to apply their intuitive laws to exempt offenders from punishment. There is a plurality of those imperatives which may conflict with each other. These reasons, however, will significantly lose their strength, if this discretion is limited by the precepts of natural law intuitively grasped by every moral agent. Even though Petrazycki did not argue for the existence of the natural law norms, its existence can be drawn from the force of attributive imperatives as well as from a striking similarity between various systems of criminal law in such diverse countries as China and Thailand.

\section{References}

Ashworth, Andrew, and Jeremy Horder. 2013. Principles of criminal law. Oxford, University Press.

Badar, Mohamed Elewa. 2013. The concept of Mens Rea in international criminal law: The case for a Unified Approach. Oxford, Hart Publishing.

Benn, Charles D. 2004. China's Golden Age: Everyday Life in the Tang Dynasty. Oxford, University Press.

Blackstone, William. 1769. Commentaries on the Laws of England. Oxford, Clarendon Press.

Chen, Jianfu. 2015. Chinese Law: Context and Transformation. Leiden, Brill.

Duff, Robin Antony. 2007. Answering for crime: Responsibility and liability in the criminal law. Oxford, Hart Publishing.

Farmer, Lindsay. 2016. Making the modern criminal law: Criminalization and civil order. Oxford, University Press.

Gorecki, Jan. 1975. Sociology and jurisprudence of Leon Petrażycki. Urbana, University of Illinois Press.

Hallevy, Gabriel. 2010. A modern treatise on the principle of legality in criminal law. Heidelberg, Springer science \& business media.

In re Levasseur, 737 F.3d 814 ( $1^{\text {st }}$ Cir. 2013).

Lijuan, Xing. 2015. The Rhyme of History: A Transition of Legal Culture in China Crowned by the Criminal Procedure Law 2012. Asia Pacific Law Review 23 (1): 31-65.

Petrazycki, Leon. 1910. Teoria Prava i Gosudarstva. St. Petersburg, Merkushev Publ.

Petrazycki Leon. 1955. Law and Morality. Cambridge, Mass., Harvard University Press.

${ }^{35}$ Ashworth A., Horder J. Principles of criminal law. P. 5. 
Rudzinski, Aleksander W. 1976. Petrazycki's Significance for Contemporary Legal and Moral Theory. American Journal of Jurisprudence 21: 107-130.

Sadurska, Romana. 1987. Jurisprudence of Leon Petrazycki. American Journal of Jurisprudence 32: 63-98.

Seredyńska, Iwona. 2011. Insider Dealing and Criminal Law: Dangerous Liaisons. Heidelberg, Springer Science \& Business Media.

Shytov, Alexander Nikolaevich. 2001. Conscience and love in making judicial decisions. Heidelberg, Springer Science \& Business Media.

Sistare, Christine T. 1989. Responsibility and Criminal Liability. Vol. 7. Heidelberg, Springer Science \& Business Media.

Tasouilas, John. 2006. Punishment and Repentance. Philosophy 81: 279-322.

Tasioulas, John. 2007. Repentance and the Liberal State. Ohio State Journal of Criminal Law 4: 485521.

Tasioulas, John. 2011. Where is the Love. The Topography of Mercy. Crime, punishment, and responsibility: The jurisprudence of Antony Duff. Eds Cruft, R., Kramer, M.H., Reiff, M.R. Oxford, University Press: 37-53.

Zarit, Steven H., and Zarit Judy M. 2011. Mental disorders in older adults: Fundamentals of assessment and treatment. New York, Guilford Press.

Received: August 20, 2017

Accepted: May 7, 2019

\section{Освобождение от наказания в Китае и Таиланде в свете теории Льва Петражицкого*}

А. Н. Шитов

Для цитирования: Chitov A.N. Exemptions from punishment in China and Thailand from the perspective of the theory of Leon Petrazycki // Правоведение. 2018. Т. 62, № 3. С. 570-581.

https://doi.org/10.21638/11701/spbu25.2018.309

В статье сравниваются законодательные положения уголовного права Китая и Таиланда в отношении освобождения от наказания, которое следует отличать от освобождения от уголовной ответственности. При освобождении от уголовной ответственности наказание невозможно. Напротив, при освобождении от наказания последнее возможно, но оно не налагается по судебному усмотрению. Законы Китая и Таиланда имеют сходство в определении освобождений от уголовной ответственности, но существенно различаются в отношении дискреционных полномочий судов по освобождению от наказаний. Китайское законодательство, в отличие от тайского, позволяет судьям иметь больше свободы действий не налагать наказания на нарушителя. Причина различий заключается в большей открытости китайского законодательства к моральным соображениям, которые следует учитывать в практике вынесения приговоров. На тайское право гораздо больше влияет философия правового позитивизма. Эти сходства и различия обсуждаются в свете теории Льва Петражицкого. Утверждается, что концепция интуитивного права, разработанная Петражицким, имеет важное значение для объяснения и оправдания полномочий суда освобождать от наказания, если это соответствует целям уголовного правосудия. С точки зрения Петражицкого, китайское право может лучше приспособить интуитивное право общественности к нуждам различных социальных ситуаций. Тем не менее теория Петражицкого сама по себе не может преодолеть многие доводы, по которым судьи не должны иметь широких полномочий применять свои интуитивные эмоции для освобождения нарушителей от наказания. Существует множество психологических факторов, которые могут конфликтовать друг с другом. Чтобы разрешить эти конфликты, необходимо опираться на идею естественного права. Несмотря на то что Петражицкий прямо не апеллировал к существованию естественного права, последнее можно вывести

* Исследование финансируется Таиландским исследовательским фондом (TRF). 
из общих психологических факторов, а также из поразительного сходства между различными системами уголовного права в таких разных странах, как Китай и Таиланд. Многие правовые положения их законов отражают определенные общие правовые парадигмы, которые не могут быть объяснены только принятием западных правовых концепций.

Ключевые слова: уголовная ответственность, наказание, Таиланд, Китай, психологическая теория права, Петражицкий.

Статья поступила в редакцию 20 августа 2017 г.; рекомендована в печать 7 мая 2019 г.

Александр Николаевич Шитов - доц., Университет Чиангмая, Таиланд, 20500, Чиангмай, ул. Хуай Keo 239; shytov@yahoo.com 